\title{
Philosophy of Science
}

Editorial Board:

Jason McKenzie

Alexander

Anna Alexandrova

Jeff Barrett

Robert Batterman

William Bechtel

Gordon Belot

Cristina Bicchieri

Katherine Brading

Richard Bradley

Jeremy Butterfield

Craig Callender

Nancy Cartwright

Lindley Darden

Michael Dickson

Stephen Downes

John Dupré

Kenny Easwaran

Allan Franklin

Doreen Fraser

Michael Friedman
Andrea Woody, Editor-in-Chief

Kevin Elliott, Alan C. Love, Angela Potochnik, Katie Steele, James Owen Weatherall, and Charlotte Werndl, Associate Editors

Peter Gärdenfors

Clark Glymour

Peter Godfrey-Smith

Alan Hájek

Stephan Hartmann

Geoffrey Hellman

Don Howard

Nick Huggett

Noretta Koertge

Marc Lange

Helen Longino

Jane Maienschein

Michela Massimi

Roberta Millstein

Sandra Mitchell

Mary Morgan

Wayne Myrvold

John Norton

Samir Okasha

David Papineau

Wendy Parker
Thomas Polger

Julian Reiss

Alan Richardson

Alex Rosenberg

Laura Ruetsche

Rose-Mary Sargent

Kristin Shrader-Frechette

Lawrence Sklar

Brian Skyrms

Chris Smeenk

Miriam Solomon

P. Kyle Stanford

Paul Teller

Derek Turner

Jos Uffink

David Wallace

C. Kenneth Waters

Marcel Weber

Rob Wilson

James Woodward

Kevin Zollman

Managing Editor: Michelle Pham

\section{Governing Board of the Association}

President: Alison Wylie, University of British Columbia

President Elect: John Dupré, University of Exeter

Past President: Sandra D. Mitchell, University of Pittsburgh

$\begin{array}{ll}\text { Hanne Andersen } & \text { Peter Godfrey-Smith } \\ \text { Alisa Bokulich } & \text { Edouard Machery } \\ \text { Hasok Chang } & \text { Laura Ruetsche } \\ \text { Megan Delehanty } & \text { Sean A. Valles }\end{array}$

Executive Director: Jessica Pfeifer 


\section{Information for Contributors}

The policies and procedures presented here are reproduced in greater detail on the editorial office's website: http://journal.philsci.org/.

Submission Method: Manuscripts should be submitted electronically via the editorial office's website: http://journal.philsci.org/submissions. All electronic files should be readable in Microsoft Word or formatted as TeX or LaTeX. (Special restrictions apply to TeX and LaTeX documents; please see the website for details.) Other correspondence with the editorial office may be sent to: Philosophy of Science, Department of Philosophy, University of Washington, Box 353350, Seattle, WA 98195, USA.

Manuscripts: Submissions must not exceed 9,500 words, including abstract, footnotes, and references; a word count must be submitted with each essay. Manuscripts should be submitted in a form suitable for blind review and should include an abstract of approximately 100 words. Authors are strongly encouraged to employ a clear, reader-friendly writing style.

Discursive footnotes (consecutively numbered) should be kept to a minimum. Simple citations can be made in the text, by citing author and year of publication (with page number if necessary); a bibliography should appear on a separate page at the end. A detailed guide to the reference style appears on the website.

Copyright: Manuscripts should be submitted to Philosophy of Science with the understanding that upon acceptance for publication copyright will be transferred to the Philosophy of Science Association.

Book Reviews: Books intended for review should be sent to the address given above. Persons wishing to review a book should contact the editorial office.

Correspondence concerning PSA business matters should be addressed to Jessica Pfeifer, Executive Director, Philosophy of Science Association, Department of Philosophy, University of Maryland-Baltimore County, Baltimore, MD 21250 (e-mail: psa@umbc.edu). The Philosophy of Science Association website is at http://philsci .org. 
Volume $87 \cdot$ Number $3 \cdot$ July 2020

\section{Philosophy of Science}

\section{Contents}

391 Quantum Randomness and Underdetermination

Jeffrey A. Barrett And Simon M. Huttegger

409 Position Measurements and the Empirical Status of Particles in Bohmian Mechanics

Dustin LaZAROVICI

425 Calibration, Coherence, and Consilience in Radiometric Measures of Geologic Time

Alisa BoKulich

457 Model Evaluation: An Adequacy-for-Purpose View WENDY S. PARKER

478 The Dual Landscape Model of Adaptation and Niche Construction Mark M. Tanaka, Peter Godfrey-Smith, and Benjamin Kerr

499 How We Think about Human Nature: The Naturalizing Error Douglas Allchin and Alexander J. Werth

518 Necessary Laws and the Problem of Counterlegals Samuel Kimpton-Nye

Essay Review

536 Review of Craig Callender's "What Makes Time Special?" James OWen Weatherall 
Philosophy of Science (ISSN 0031-8248) is published January, April, July, October, and December by The University of Chicago Press, 1427 E. 60th Street, Chicago, IL 60637.

Periodicals postage paid at Chicago, IL, and at additional mailing points.

Postmaster: Send address changes to Philosophy of Science, The University of Chicago Press, 1427 E. 60th Street, Chicago, IL 60637, or subscriptions@ press.uchicago.edu.

\section{Membership and Subscription Rates}

Individual subscription rates for 2020 are tiered based on income and start at \$36 print + electronic, \$27 e-only. Institutional print + electronic and e-only subscription rates are tiered according to an institution's type and research output: \$307 to \$645 print + electronic, $\$ 267$ to $\$ 561$ e-only. Institutional print-only is $\$ 352$. Additional taxes or postage for non-US subscriptions may apply. For additional rates, including full-run access, rates for single copies, and reduced rates for students, visit http://www.journals .uchicago.edu/journals/phos/about. Free or deeply discounted access is available in most developing nations through the Chicago Emerging Nations Initiative (http:// www.journals.uchicago.edu/ceni).

\section{Editorial Correspondence}

Send all editorial correspondence to Philosophy of Science, Department of Philosophy, University of Washington, Box 353350, Seattle, WA 98195. E-mail: journal@philsci .org. Information regarding submission of manuscripts can be found on the inside back cover of every issue or on our website: http://journal.philsci.org.

\section{Copying Beyond Fair Use}

Articles may be copied or otherwise reused without permission only to the extent permitted by Sections 107 and 108 of the US Copyright Law. Permission to copy articles for personal, internal, classroom, or library use may be obtained from the Copyright Clearance Center (http://www.copyright.com/). For all other uses, such as copying for general distribution, for advertising or promotional purposes, for creating new collective works, or for resale, please contact Permissions Coordinator, Journals Division, University of Chicago Press, 1427 E. 60th St., Chicago, IL 60637, USA. Fax: (773) 834-3489.E-mail:journalpermissions@press.uchicago.edu.Articles in the public domain may be used without permission, but it is customary to contact the author.

Articles appearing in Philosophy of Science are abstracted or indexed in Arts and Humanities Citation Index, Biological Abstracts, Bulletin Signalétique 519, Current Contents/Arts and Humanities, Current Contents/Social and Behavioral Sciences, Current Index to Statistics, Humanities Index, Index to Book Reviews in the Humanities, Isis Critical Bibliography, Language \& Language Behavior Abstracts, Mathematical Reviews, Philosopher's Index, Philosophic, Psychological Abstracts, Repertoire Bibliographique de la Philosophie, Social Sciences Citation Index, Sociological Abstracts.

(C) 2020 by Philosophy of Science Association. All rights reserved. 